\title{
Corporate Social Responsibility Awareness of Selected Private School Teachers in Camarines Norte
}

\author{
Andrew Emmerson P. Abilgos, MBA ${ }^{1}$, Dr. Girly H. Naval ${ }^{2}$ \\ ${ }^{1,2}$ Camarines Norte State College
}

\begin{abstract}
This study was conducted to determine the level of awareness of Corporate Social Responsibility of selected private school teachers in Camarines Norte, 176 teachers provided the necessary data to accomplish this feat and were done through the administration of questionnaire and interviews to get additional information. The study employed a descriptive survey method of research.

The study revealed the following: (1) there are more female respondents than males, 52 percent and 48 percent respectively, 62 percent are 30 years old and younger, which gained the largest concentration. All the respondents have completed tertiary education and 63 percent of the respondents have tenures of 10 years or less. (2) The level of awareness on CSR is highly aware in terms of both ethical and philanthropic areas. (3) The measure that may be formulated in order to still improve and maintain the knowledge, awareness and involvement of corporate social responsibility of the teachers are to keeping purposeful track of the teacher's core CSR values orientation and regular seminars and workshops aimed to improve the understanding of corporate social responsibility. Based on the findings of the study, it may be concluded that the respondents have ample awareness in corporate social responsibility.
\end{abstract}

KEYWORDS: Awareness; Corporate Social Responsibility; Private School Teachers

\section{INTRODUCTION}

Corporate social responsibility or most commonly as CSR has been rapidly gaining importance all over the world. Throughout the years, the concept of corporate social responsibility (CSR) has continued to grow in prominence and significance stretching to corporations, Small-Medium Enterprises as well as different field of study and expertise. It has been the subject of extensive debate, commentary, annotation, theory building, research and studies. Despite the continuing deliberations as to what it means and what it really and should embrace, it has advanced and evolved in both academic perspective as well as the common practice worldwide.

The idea that business enterprises and organizations have the responsibility that goes beyond their normal profit-making operation and stretches to their immediate community and beyond have been around for quite some time already. Lately, the practice of responsible annual CSR reports generated by international and national companies have been included in their standard corporate practices. The strengthened quest for sustainable business practices in recent times has shifted how these enterprises view corporate social responsibility and how to introduce it to their standard operation.

Companies have started inculcating a sound CSR in the core of their business as to the belief that it is critical to the longterm sustainability and their industrial success. Businesses do not exist in isolation of their immediate community and beyond, they create products and services to serve their needs for the purpose of profit making, while maintain their responsibility to different stakeholders and the society in general.

United Nations Industrial Development Organization (UNIDO) stated that Corporate Social Responsibility is a management concept whereby companies integrate social and environmental concerns in their business operations and interactions with their stakeholders. The balance of environmental, economic and social necessities is what a company achieves in the conduct of CSR.

One concept that is being linked to CSR is the triple bottom line concept (TBL or 3BL). The concept was first conceived in the year 1994 by John Elkington, an author, consultant and authority on corporate responsibility as well as sustainable development. The idea is that should be aimed at three varied bottom lines for the company. The first and foremost is the economic 


\section{International Journal of Current Science Research and Review}

ISSN: 2581-8341

Volume 04 Issue 07 July 2021

DOI: 10.47191/ijcsrr/V4-i7-05, Impact Factor: 5.825

IJCSRR @ 2021

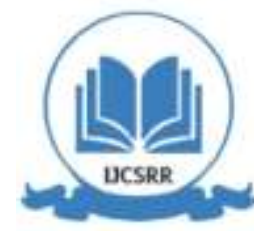

www.ijesrr.org

bottom line a very traditional approach to corporate sustainability and profitability. The next would be the social equity bottom line which is a measure the company's accountability to its society within the boundary of its operation. The third and last is the environmental bottom line which is a measure of the accountability of the company to be responsible to its environment and planet. One of the easiest ways to grasp the concept's main point is to understand the three P's: profit, people and planet. The idea is to measure the long-term performance of the business in terms of financial, social and environmental aspects over a period of time.

Correspondingly, the orientation given to students at school have always been traditionally focused on a business' idea of exclusiveness of the aim for economic factor of business endeavor. Such notion involves the concept of the maximization of profit above all else. This is agreed by Milton Friedman, an American economist and Nobel Prize winner. He stated that, "There is only one social responsibility of business and that is to increase the profit of the shareholders. Profit maximization is not just a fiduciary responsibility, but also a social responsibility and in fact, the only responsibility." Such statement turns out to be a controversial statement during those time specially in the business world (Mertens, 2013).

Furthermore, Corporate Social Responsibility (CSR) has been a long and widely discussed concept in research fields and among practitioners. Though, there is no generally agreed precise definition of CSR, there is a common aspect in most meanings and explanations and it entails that CSR is a voluntary integration of the social and environmental concerns by businesses beyond its normal business compliance (Hoeve, 2016).

In the Philippines, CSR has significantly evolved in the past several decades. According to the Philippine Business for Social Progress (PBSP), one of the country's most active CSR organizations, consumers today have a higher regard for companies that engage in CSR activities and initiatives. CSR awareness among Philippine businesses began in the 1960s, such as giving donations in cash directly to foundations and other charitable organizations.

In September 2013, House Bill 306 otherwise known as the "Corporate Social Responsibility Act of 2013" was re-filed in the 16th Congress by Pampanga Rep. Gloria M. Arroyo (2nd District) and Camarines Sur Rep. Diosdado M. Arroyo (2nd District) that mandate corporations to consider the interests of society by taking responsibility for the impact of their activities on customers, employees, shareholders, communities and the environment in all aspects of their operations.

Although the Corporate Responsibility Act of 2013 has not yet been recognized there are certain laws that may be a basis for the adoption of CSR practices relating to ethical and environmental sound practices. Philippine laws such as Republic Act 9003: Ecological Solid Waste Management Act of 2000, Republic Act 9275: Philippine Clean Water Act of 2004 and R. A. 6715 which is most commonly known as the Labor Code of the Philippines.

Based on the data published by the Philippine Statistic Authority, Camarines Norte registered a 21.7 percent in its poverty prevalence. By the year 2015, it has increased to 29.3 percent. This increase is notable because one of the aims of CSR is to alleviate social problems and innovate ways to better improve the social state of the community.

There is not much study and information regarding the corporate social responsibility awareness of private school teachers in Camarines Norte. Identifying the CSR level of awareness of teachers will fill in these gaps. These factors stimulated the initiative of the present study. Teachers are one of the primary sources of CSR education, and it is relevant that it is studied in order to create a better grasp on their knowledge and cognizance in different areas of corporate social responsibility.

\section{METHODOLOGY}

The study employed descriptive method of research. The descriptive method was employed because it dealt with the profile of the respondents and investigated the level of awareness on CSR of the selected private school teachers in Camarines Norte. The study was limited to the 176 respondents and only private school teachers were selected as the respondents. Purposive sampling was used as the sampling technique to be utilized int eh study. Purposive sampling was used because of the specificity of the study and the need for the data to be derived from specific type of respondents.

The main data-gathering instrument in the study that was used was a survey questionnaire. Data were also gathered through informal interview to grasp the notion of the respondents in connection with the CSR and act as supplemental data. The questionnaire was separated into two (2) parts namely: profile of the respondents and level of CSR awareness. The data gathered in this study 


\section{International Journal of Current Science Research and Review}

ISSN: 2581-8341

Volume 04 Issue 07 July 2021

DOI: 10.47191/ijcsrr/V4-i7-05, Impact Factor: 5.825

IJCSRR@ 2021

www.ijesrr.org

were analyzed and interpreted through the use of various statistical tools. Percentage frequency distribution techniques used to evaluate each corresponding respondent to the total respondents. This identified the recurring factors in the study. The technique was used to display the specific percentage of observation that existed for each of the indicator in the profile, while the weighted mean was employed to determine the level of awareness of the respondents. The study is limited to the CSR areas along the ethical practices and Philanthropic efforts.

\section{RESULTS AND DISCUSSIONS \\ Profile of the Respondents}

Figure 1 to 4 presented the profile of the respondents as to their sex, age, educational attainment and years of service.

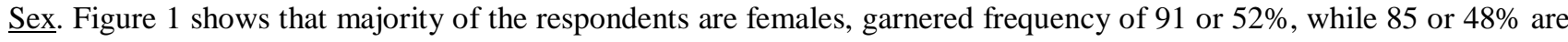
males. The females dominated the population of the respondents gaining more than half of the total respondents.

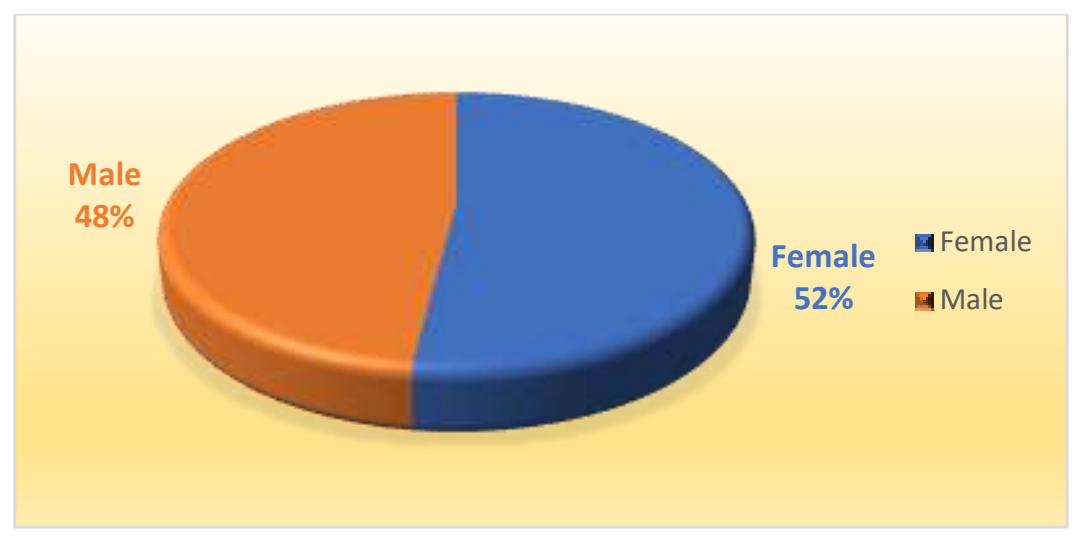

Figure 1. Proportion breakdown of the Sex Profile of the Respondents

This indicates that more women tend to teach in the academic institutions in Camarines Norte rather than men. The study has confirmed such findings on the majority of the teachers in private schools. The women are more susceptible to being teacher because of the natural order of things that women tend to be influenced by child-caring jobs and this leads to a majority of female teachers. This implication is being affirmed by Skelton (2009), in which the author's study indicated that teaching at school has long been believed and assumed to be primarily a woman's profession and job because working with children was often associated with predominantly child-care rather than teaching.

Age. Majority of the respondents (108 or 62\%) are between 21 and 30 years old. The age bracket with the most respondents is ages 21 to 25 years old with 77 (44\%), followed by ages 26 to 30 years old with 31 (18\%), then 31 to 35 years old with 23 (13\%). Respondents from the most senior age bracket, ages 46 and above, which were the fourth largest age group got 20 (11\%).

The data show that employees with the age range 21-25 have the highest concentration among the respondents. This result is due to the high demand for teachers, and newly graduate teachers tend to seek employment from private academic institutions to gain formal teaching experience. This kind of trend in the Philippines causes the surge of younger generation of teachers in private schools. The lowest result came from respondents with ages 46 and above. These are employees who are 46 years old and above, and have long tenure with the institution, and who are nearing their retirement. The younger teachers outnumbered the older ones because there is more influx of newly graduate teachers in all of the private schools in the country. Newly graduates tend to seek employment in private schools to earn ample professional experience in their field. This is maybe because of the generation gap between the students and older teachers. The older teachers may not be able to cope with the changing pupil behaviors. This is also stated in the aforementioned paragraph justifying the increase in younger teachers. 


\section{International Journal of Current Science Research and Review}

ISSN: 2581-8341

Volume 04 Issue 07 July 2021

DOI: 10.47191/ijcsrr/V4-i7-05, Impact Factor: 5.825

IJCSRR@ 2021

www.ijcsrr.org

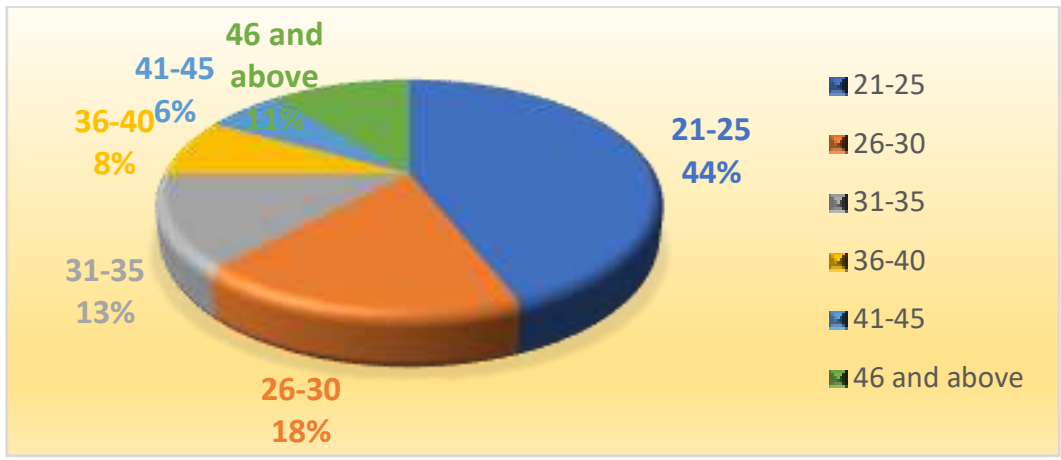

Figure 2. Proportion breakdown of the Age Profile of the Respondents

According to the article by Veteran Filipino Journalist (VERA) Files in the Philstar global website, in previous years, enrollment in the education courses and teacher training track at all levels in tertiary education has ascended from being the third to the second most popular courses among tertiary track. Within a five-year period, education track students that graduated have increased significantly. In the academic year 2010-2011, the total finished teacher education courses finishers totaled to of 62,715; by academic year 2015-2016, graduated increased to 116,305 students. With the influx of education courses graduates, this in turn ma increase the supply of newly and fresh graduate teachers that are willing to teach in the private schools to gain more experience. Private schools in the Philippines have a more lenient requirement on becoming a teacher rather than the public sector. this causes the surge of younger generation of teachers in private schools in their early years as professionals.

Educational Attainment. The highest educational attainment of majority of the respondents (113 or 64\%) is the Bachelor's Degree; 50 respondents (28\%) have Master's Degree, while 13 (8\%) have Doctoral Degree.

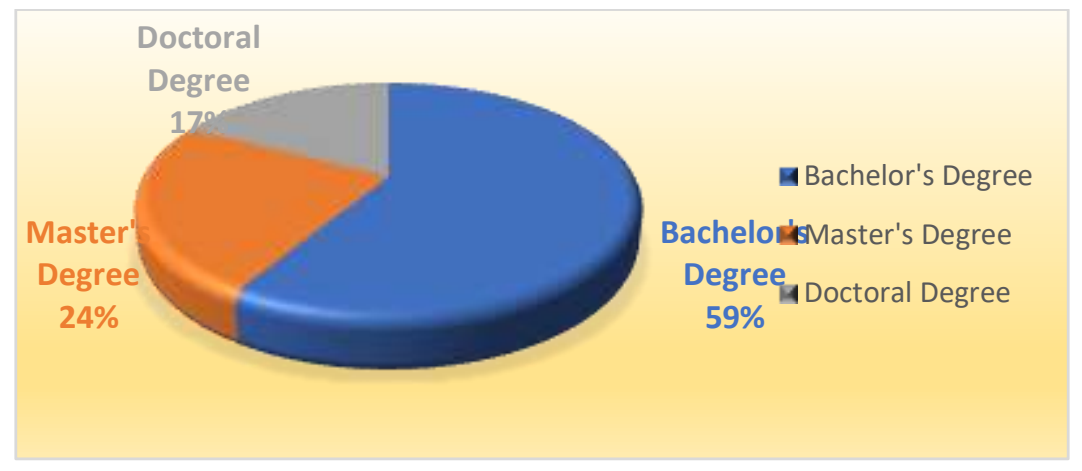

Figure 3. Proportion breakdown of the Highest Educational Attainment

\section{Profile of the Respondents}

The highest concentration of the respondents has bachelor degree under their belt. No respondents have the educational background of elementary, high school, and vocational degree. This may be connected to the certain requirement of the teaching profession. The teaching profession has a minimum requirement of a bachelor's degree for it is the standard form of requirement for most of the professional job in the Philippines. The graduate must possess at least and education degree or of equivalent or higher qualification. The lowest result came from doctorate degree holders, while obtaining further studies like masters and doctorate degrees are done in order to gain more foothold in the employment pool, not many people continue to seek doctorate degree because of the time constraints and the load it takes to get it.

The higher concentration of respondents having at least a bachelor degree is connected to the minimum basic requirements of being a teacher in the Philippines. A minimum educational qualification of a bachelor's degree in education for a teaching personnel in the kindergarten and elementary levels. Meanwhile in the secondary level in academic subject - a bachelor's degree in 


\section{International Journal of Current Science Research and Review}

ISSN: 2581-8341

Volume 04 Issue 07 July 2021

DOI: 10.47191/ijcsrr/V4-i7-05, Impact Factor: 5.825

IJCSRR@ 2021

www.ijcsrr.org

education, or equivalent, or a bachelor's of arts, with such additional number of professional education subjects as may be required, to teach largely in their major or minor fields of concentration. Additionally, for vocational subjects the teacher should be knowledgeable of the vocational courses to be taught. It is emphasized that the provision of minimum educational qualification for teaching personnel, the manual still prescribes that teaching personnel in private basic education institutions should have passed the Licensure Examination for Teachers (LET), except for instances allowed by law (DO 88, S. 2010).

Years in Service. Data from the survey revealed that consistent with the distribution per age bracket, most of the respondents have tenures of 10 years or less; 78 (44\%) have tenures of between 1 to 5 years; and 33 have been in the service for 6 - 10 years $(19 \%)$. Meanwhile, $26(15 \%)$ have careers spanning 11 to 15 years. Respondents whose tenures are beyond 15 years represent $22 \%$ of the sample size.

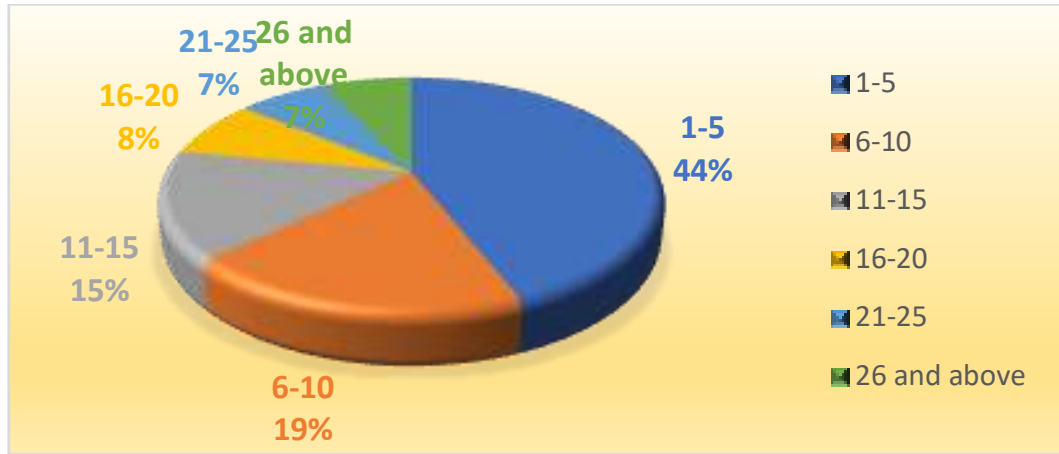

Figure 4. Proportion breakdown of the Years in Service Profile of the Respondents

The respondents with 1 to 5 years of service have the highest concentration because as seen in table 2, these are employees that are the newest pool of teachers. As stated in the previous table, the high concentration of younger generation is because of the number of applicants that private schools have in terms of newly graduate teachers. The lowest result came from the employees with 26 and above years of service. The reason behind this was maybe because these employees have really settled on the academic institutions that they are in and are just waiting for their retirement period.

As stated in the previous discussion, there is a high concentration of younger generation in the private schools is because of the increase of applicants that private schools have in terms of newly graduate teachers. According to Section 8 of the Enhanced Basic Education Act of 2013, states that graduates of the courses such as science, statistics, mathematics, engineering, music, and other degree courses with scarcities in qualified Licensure Examination for Teachers (LET) applicants are permitted to teach in specialized subjects in the elementary and secondary education. Qualified LET applicants shall also include graduates admitted by institutions duly recognized for education sector expertise and who satisfactorily completed the requirements set by the governing bodies; such provision indicates that they are required to pass the LET examination within five (5) years after their date of hiring; in the case that applicants are willing to teach on part-time basis, the aforementioned provision of LET shall no longer be required

\section{Level of Awareness of the Selected Private School Teachers on Ethical Practices and Philanthropic Efforts}

Data on the respondents' level of awareness were gathered with focus on ethical practices and philanthropic efforts. The survey aimed to determine how significant the awareness level is among the respondents.

Ethical Practices. The survey reveals that respondents are highly aware of the specific CSR indicators along the area of ethical practices. The average weighted mean across indicators is 4.10 . The highest result is equal opportunities for employees with a weighted mean of 4.19 ; followed by fair salary wages at 4.10 ; career development programs and improving labor practices at 4.08 ; and lowest result is from the promotion of community involvement with a weighted mean of 4.06.

Equal opportunities for employees received the highest weighted mean at 4.19. Interviews with the respondents reveal that this is the most relevant and significant to employees of academic institutions. Equal opportunities for employee gained the highest which might be because the main impact of such indicator is directed to the employees, and that they can relate to the situation at 


\section{International Journal of Current Science Research and Review}

ISSN: 2581-8341

Volume 04 Issue 07 July 2021

DOI: 10.47191/ijcsrr/V4-i7-05, Impact Factor: 5.825

IJCSRR@ 2021

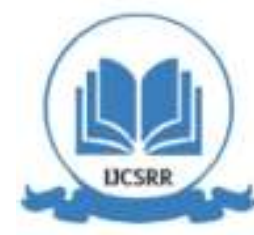

www.ijcsrr.org

hand. Meanwhile, promotion of community involvement received the lowest weighted mean though still within the highly aware bracket. Such result is possible for private institutions because the institution may view it as low priority. It can also be because there are constraints in implementing community involvement like the organizational approach and management behavior.

Table 1. Level of Awareness of the respondents along Ethical Practices

\begin{tabular}{rlll}
\hline \hline Indicators & Weighted Mean & Interpretation \\
\hline 1. & Equal opportunities for employees & 4.19 & HA \\
2. & Fair salary wages & 4.10 & HA \\
3. & Career Development Programs & 4.08 & HA \\
4. Improving labor practices & 4.08 & HA \\
5. & Promotion of community involvement & 4.06 & HA \\
& Average Weighted Mean & 4.10 & Highly Aware \\
\hline Legend: & &
\end{tabular}

$\begin{array}{ll}\text { 4.51-5.00 } & \text { - Extremely Aware (EA) } \\ 3.51-4.50 & \text { - Highly aware (HA) } \\ 2.51-3.50 & \text { - Moderately Aware (MA) }\end{array}$

1.51-2.50 - Slightly Aware (SA)

1.00-1.50 - Not Aware (NA)

These results show that employees recognize the relevance of these indicators beyond the academic institution's objectives, but more so because they feel strongly about it. Ali (2010), the more relatable people are to CSR issue the more people are made aware of such indicators, or in case of other CSR issue that are currently requiring immediate resolution or action. As such, equal opportunities for employees are something that most employees can easily relate for it is something that are sought by employees in a workplace. It is not uncommon that cases of partiality may occur or present within organizations, thus equality is sought after by most employees.

Philanthropic Efforts. While the average weighted mean across indicators of philanthropic efforts is lower and the range is wider compared to its counterpart results in ethical practices, the data in Table 2 shows that the level of awareness across all indicators is towards the higher end. There were different variables that were included in the table. The highest indicator is Scholarship programs and the lowest is medical missions.

Table 2. Level of Awareness of the respondents along Philanthropic Efforts

\begin{tabular}{cll}
\hline \hline Indicators & Weighted Mean & Interpretation \\
\hline 1. Community Outreach & 4.11 & HA \\
2. Scholarship Programs & 4.24 & HA \\
3. Community Livelihood Programs & 3.86 & HA \\
4. Waste Management & 4.10 & HA \\
5. Medical Missions & 3.71 & HA \\
Average Weighted Mean & 4.01 & Highly Aware \\
Legend: & & $1.51-2.50 \quad-$ Slightly Aware (SA) \\
4.51-5.00 - Extremely Aware (EA) & \multicolumn{2}{c}{ 1.00-1.50 - Not Aware (NA) } \\
3.51-4.50 - Highly aware (HA) & &
\end{tabular}

Respondents are highly aware of each indicator, with awareness in scholarship grants as the highest and medical missions acquired the lowest result. Scholarship programs are high because it is common for academic institutions to offer in-house scholarships such as student assistant and academic scholarship. This also applies to external scholarships. This can also apply to graduate and post-graduate studies of the employees. Such provisions can be seen in academic institutions in hosting the further studies of their employees. Medical missions gained the lowest weighted mean among the indicators. This may be the results having low number of schools that are medically inclined. Thus, the capacity and capability of the schools to initiate such program with 


\section{International Journal of Current Science Research and Review}

ISSN: 2581-8341

Volume 04 Issue 07 July 2021

DOI: 10.47191/ijcsrr/V4-i7-05, Impact Factor: 5.825

IJCSRR @ 2021

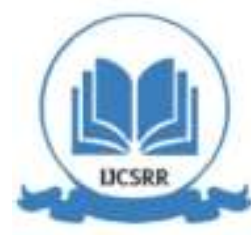

www.ijesrr.org

ease is deterred. It may also be because these programs are usually conducted by NGOs, civic organizations, and even religious organizations across the world.

According to the PHD Chamber in India through their Global CSR Summit have stated that providing scholarships to disadvantaged students is another common activity being observed with $62 \%$ of all companies offering some form of scholarships. Moreover, Bauman et al. (2012) explains that philanthropic activities that hit closest to home among employees has the strongest impact in terms of awareness.

\section{CONCLUSIONS}

Based on the result of the study, it is to be noted that there is a high awareness on the corporate social responsibility of the teachers in the areas of ethical practices and philanthropic efforts. The level of awareness is "highly aware" across the board Nevertheless, there is always room for improvement not only in the knowledge but also in commitment and involvement to corporate social responsibility. The recommended measures that may be formulated in order to still improve and maintain the knowledge, awareness and involvement of corporate social responsibility of the teachers are to keep purposeful track of the teacher's core CSR values orientation; regular seminars and workshops aimed to improve the understanding of corporate social responsibility; continuous engagement in economic and cultural development of the community; and to enhance focus on community extension to get more people involved so that their community can become more responsive to leveling up social and ethical norms.

\section{REFERENCES}

1. Business World Online. (2018). Corporate Responsibility Bill Re-Filed in Congress. Retrieved August 2, 2018 from http://www.bworldonline.com/content.php?section=Nation\&title=corporate-responsibility-bill-refiledincongress\&id=76 798

2. Flores, A. M. (2018). CSR in the PH: An Evolution Based on Service to Others. Retrieved August 30, 2018 from http://manilastandard.net/spotlight/ms-31st-anniversary-growing-business-beyond-profit/258495/csr-in-the-ph-anevolution-based-on-service-to-others.html

3. Hoeve, S. V. (2016). Corporate Social Responsibility: One Term, Different Approaches. Unpublished Master's Thesis. Radboud University, Nijmegen School of Management, Nijmegen, Netherlands, August 2016

4. Labor Code of the Philippines. Retrieved September 3, 2018 from https://www.lawphil .net/statutes/repacts/ra1989/ra_6715_1989.html

5. Philippine Statistics Authority. (2015) Annual Per Capita Poverty Threshold, Poverty Incidence and Magnitude of Poor Families, by Region and Province: 1991, 2006, 2009, 2012 and 2015. Retrieved August 13, 2018 from https://psa.gov.ph/sites/default/files/Table\%201.\%20\%20Annual\%20Per\%20Capita\%20Poverty\%20Threshold\%2C\%20 Poverty $\% 20$ Incidence $\% 20$ and $\% 20$ Magnitude $\% 20$ of $\% 20$ Poor $\% 20$ Families $\% 2 \mathrm{C} \% 20$ by $\% 20$ Region $\% 20$ and $\% 20$ Province $\% 20 \% 20-\% 202006 \% 2 \mathrm{C} \% 202009 \% 2 \mathrm{C} \% 202012 \% 20$ a nd\%202015.xlsx

6. Triple bottom line. (2009). Retrieved August 2, 2018 from https://www.economist .com/news/2009/11/17/triple-bottomline

7. United Nations Industrial Development Organization. (2018) What is CSR?. Retrieved August 28, 2018 from https://www.unido.org/our-focus/advancin g-economic-competitiveness/competitive-trade-apacitiesand-corporateres ponsibility/corporate-social-responsibility-marketintegratio $\mathrm{n} /$ what-csr

8. Republic Act 9003: Ecological Solid Waste Management Act of 2000. (2000). Retrieved August 28, 2018 from https://www.lawphil.net/statutes/repacts/ra2001/ra_9003_2001.html

9. "Republic Act 9275: Philippine Clean Water Act of 2004." (2004). Retrieved September 3, 2018 from https://www.lawphil.net/statutes/repact/ra2004/ra_9275_2004.html

10. Downie, N. M., and Heath, R. W. Basic Statistical Methods. New York. Harper. 1959. pp. xii, 289

11. Skelton, C. (2009). Failing to get men into primary teaching: a feminist critique. Journal of Education Policy, (24)1, 3954

12. Vera Files (2017). Teacher Education Regains Popularity. Retrieved February 2, 2019 from https://www.philstar.com/headlines/2017/06/08/1707962/teac hereducation-regains-popularity

13. DO 88, S. 2010 - 2010 REVISED MANUAL OF REGULATIONS FOR PRIVATE SCHOOLS IN BASIC EDUCATION. 


\section{International Journal of Current Science Research and Review}

ISSN: 2581-8341

Volume 04 Issue 07 July 2021

DOI: 10.47191/ijcsrr/V4-i7-05, Impact Factor: 5.825

IJCSRR@ 2021

www.ijcsrr.org

Retrieved from https://www.deped.gov.ph/2010/06/24/do-88-s-2010-2010-revised-manual-of-regulations-for-privateschools-in-basic-education-amended-by/

14. Republic Act No. 10533 - An Act Enhancing The Philippine Basic Education System By Strengthening Its Curriculum And Increasing The Number Of Years For Basic Education, Appropriating Funds Therefor And For Other Purposes. Retrieved

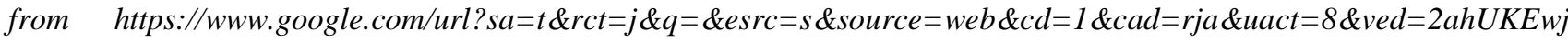
Ep624ttTgAhUOrpQKHZMGAZgQFjAAegQIBxAB\&url=https\%3A\%2F\%2Fwww.officialgazette.gov.ph\%2F $2013 \% 2 F 0$ $5 \% 2$ F 15\%2Frepublic-act-no10533\%2F\&u sg=AOvVaw03k4EbFclZhroI5aFY1Cea

15. Ali, I., Rehman, K. U., Ali, S. I., Yousaf, J., and Zia, M. (2010). Corporate social responsibility influences, employee commitment and organizational performance. African Journal of Business Management, 4 (12), 2796- 2801.

16. Werner, W. (2009). Corporate Social Responsibility Initiatives Addressing Social Exclusion in Bangladesh. Journal of Health, Population and Nutrition. Retrieved February 22, 2019 from https://www.ncbi.nlm.nih.gov/pmc/articles/PMC2928 098/

17. Bauman, C., and Skitka, L. (2012). Corporate Social Responsibility as a Source Of Employee Satisfaction. Research in Organizational Behavior.

Cite this Article: Andrew Emmerson P. Abilgos, MBA, Dr. Girly H. Naval (2021). Corporate Social Responsibility Awareness of Selected Private School Teachers in Camarines Norte. International Journal of Current Science Research and Review, 4(7), 643650 